\title{
The Adaptation of Learning Strategies for Higher Education Scale for Turkish Context
}

\author{
Sayime Erben Kecici \\ Dr. Necmettin Erbakan University, Turkey, sayime_erben@yahoo.de
}

Mustafa Aydın

Dr., Necmettin Erbakan University, Turkey, maydin@konya.edu.tr

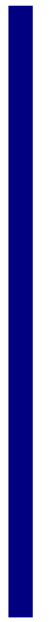

In this study, it is aimed to adapt the LIST scale that was prepared by Boerner et al. (2005) to define the learning strategies of university students, to Turkish. Validity and reliability analysis were made for Turkish form considering the original form. The study was conducted with 754 college students. Firstly, the linguistic equivalency of the scale was completed then the factor structure was analyzed. The factor structure of the scale was commented considering the exploratory factor analysis and parallel analysis results. Statistically irrelevant items were excluded from the scale. Factor analysis results show that the scale was 12 dimensional and consists of 67 items. According to the analyses, the internal consistency of 12 dimensional structure of the scale was adequate with the factors in the scale. Cronbach Alpha values of the factors ranged between .74 and .92 . Furthermore, in order to ensure the reliability of the scale, comparisons of item averages of between sub and super groups were made. It was seen that the results of the comparisons of $27 \%$ sub and super groups were significant factor all the items. These results show that the 12 dimensional structure of the scale is valid and reliable to define the learning strategies of university students.

Keywords: scale adaptation, learning strategies, higher education, Turkish context, factor analysis

\section{INTRODUCTION}

In information age, students need to take the responsibility of their own learning and they need to be aware of what they know and how to learn. Accordingly, one significant resource of success which is an indicator of the degree at which a student benefits from a lesson or an academic program in a school setting is students' taking the responsibility of their own learning (Zimmerman, 1994). As the view that a student is an active participant who can organise his/her own learning has become dominant, learning to learn has become one of the most significant issues in the field of education. The

Citation: Kecici, S. E., \& Aydın, M. (2019). The Adaptation of Learning Strategies for Higher Education Scale for Turkish Context. International Journal of Instruction, 12(1), 1413-1430. https://doi.org/10.29333/iji.2019.12190a 
fundamental characteristics of learning to learn are to be aware of yourself, to be aware of your own learning style, to know the strategies that facilitate learning, and to choose and use the strategies that are the most appropriate. At this point, as learning through internalisation of knowledge rather than learning by heart has come into prominence, the level of students' awareness regarding their learning strategies has gained importance.

In the literature, various definitions have been suggested for learning strategies. Weinstein and Mayer (1986) defined learning strategies as behaviours and ideas that are expected to affect the coding process and be realised during the learning stage. In this way, they emphasised that learning strategies can affect students' motivational and emotional state and how they choose, acquire, organise and integrate knowledge. According to another definition, learning strategies are the process steps that individuals use in their decision-making process. (Zhang \& Sternberg, 2001; Cited by: İflazoğlu Saban \& Tümkaya, 2008).

According to Gagné et al. (2005) learning strategies are intrinsic processes that students utilise to choose and organise how to learn, remember and think better. Şimşek (2006) defined learning strategies as the body of the approaches students use to carry out academic tasks or to improve their social skills in the process of learning. When the definitions provided are analysed, it can be argued that the common points that are underlined are the behaviour and thinking processes that students utilise to make their own learning more qualified, efficient and lasting.

When the literature was reviewed, it was seen that there is not a consensus on the categorisation of learning strategies and different researchers categorise these strategies in various ways. Namely, in the literature there are different categorisations for learning strategies. Although there are different namings for the strategies, it can be argued that affective, cognitive and metacognitive strategies are mentioned in each categorisation.

Affective strategies existed in the categorisations of Weinstein and Mayer (1986), Öztürk (1995), Subaşı (2000) and Şimşek and Deryakulu (1994). Affective strategies which were mentioned as motivational strategies in some of these categorisations are the strategies which are about creating a context in which students realise their learning. Motivational strategies also help remove motivational and affective obstacles.

Most of the studies on cognitive strategies are based on the categorisations of Weinstein and Mayer (1986) and Gagné and Driscoll (1988). Şimşek (2006) defined cognitive strategies as the body of approaches that students use to undertake their academic duties or to enhance their own social skills during the learning process. Cognitive strategies are named as the strategies that increase rehearsal, interpretation, organisation, attention and retrieval. Rehearsal strategies that are a part of the cognitive strategies are also mentioned in the categorisations offered by Gagné and Driscoll (1988), Pintrich, Smith, Garcia and McKeachine (1991), Özer (1998) and Subaşı (2000). Weinsteing and Mayer (1986) studied rehearsal strategies in two different dimensions: basic and complex. The rehearsal strategies in basic learning are composed of students' rehearsal of the presented material in a way to memorise it and also the transfer of the selection and acquisition of units to short-term memory. In complex learning, on the other hand, 
rehearsal strategies have two objectives: The first one is selection which is paying attention to the significant components of an item and the second one is realisation of recognition which is the transfer of the learned items into short-term memory. In some classifications offered by pedagogues, rehearsal strategies may be named as repetition strategies or the strategies that increase storing in short-term memory. The interpretation strategies mentioned in Weinstein and Mayer's (1986) categorisation were also mentioned in a similar way in the categorisations of Öztürk (1995), Özer (1998), Subaş1 (2000) and Senemoğlu (2005). In general, the goal of interpretation strategies is to form associations among the learned concepts. The interpretation strategies used in complex learning aim to help integrate students' target new knowledge with the already existing one by which the new information is coded into the long-term memory (Weinstein \& Mayer, 1986). Weinstein and Mayer (1986), Pintrich, Smith, Garcia and McKeachine (1991), Özer (1998) and Şimşek and Deryakulu (1994; cited by Şimşek, 2006) included organisation as a strategy in their categorisations. Organisation strategies are a special form of interpretation strategies and they support the interpretation of the material to be learned by restructuring and organising. Attention strategies that are a part of Gagné and Driscoll's (1998) categorisation were also mentioned in Öztürk (1995), Subaşı (2000) and Senemoğlu's (2005) categorisations. According to Gagné and Driscoll (1998), attention strategies are the strategies that students use carefully and consciously to choose the materials they will learn. Another cognitive strategy that takes place in categorisations is the one that increases retrieval. Mnemonic devices, simulations, envisaging, analogies, asking yourself questions and note taking are the instances of strategies that facilitate retrieval (restoring and remembering).

Metacognitive strategies are the monitoring skills that learners actively use while they are learning. Metacognitive means being aware of how one learns and it is to know how learning takes place in addition to learning and understanding anything. Metacognitive strategies are the ones in which an individual puts his/her knowledge regarding his/her own cognitive system, its structure and working style to use (Senemoğlu, 2010). The strategy of monitoring learning which exists in the categorisations of the studies of Weinstein and Mayer (1986), Gagné and Driscoll (1988), Pintrich, Smith, Garcia and McKeachine (1991) and Özer (1998) is named as the strategy of managing the cognition by Öztürk (1995); executive cognitive strategies by Senemoğlu (2005) and intrinsic check strategies by Şimşek and Deryakulu (2006; cited by Şimşek, 2006). The strategy of monitoring learning enables an individual to be aware of his/her thinking and learning ways, and to regulate his/her learning efficiently (Gagné and Driscoll, 1988).

In the literature many studies demonstrated that, no matter which learning strategy categorisation is taken into consideration, the correct and efficient use of learning strategies increases academic success, which leads to better and lasting learning (Ülger, 2003; Y1ldız, 2003; Haşlaman \& Aşkar, 2005; Üredi \& Üredi, 2005; Lynch, 2006; Belet \& Yaşar, 2007; Dikbaş \& Hasırc1, 2007; Tunçer \& Güven, 2007; Diseth, 2011; Baş, 2012; Muelas \& Navarro, 2015). Learning strategies provide learners with quick and lasting learning, they increase efficiency in learning and they earn learners independent learning skills (Apps, 1990; Lorenger, 1994; Weinstein \& Macdonald, 1986). Accordingly, students should be equipped with the abilities of identifying, utilising, 
monitoring and evaluating the learning strategies and they should be taught when and how to use these strategies (Karakış \& Çelenk, 2007). In order for students to use learning strategies efficiently, initially their learning strategies must be identified. There are different learning strategies scales to identify the learning strategies students have. One of them is MSLQ (Motivated Strategies for Learning Questionnaire) which was developed by Pintrich and De Groot (1990). The adaptation of this scale into Turkish, and its reliability and validity tests were undertaken by Büyüköztürk, Akgün, Özkahveci and Demirel (2004) and Altun and Erden (2006) on undergraduate students. The adaptation of the scale, developed by Schraw and Dennison (1994) to identify the metacognitive awareness levels, into Turkish was done by Akın, Abacı and Çetin (2007). The scale consisting of 52 items has declarative, procedural and contextual knowledge factors in its knowledge of cognition dimension while it has planning, management and organisation of knowledge, monitoring, error elimination and evaluation factors in its regulation of cognition dimension. In their study O'Neil and Abedi (1996) developed a scale to identify 12th grade students' learning strategies. The scale which was founded upon self-assessment consists of 4 dimensions and 20 items in total. The dimensions in the scale are specified as "awareness", "cognitive strategy", "planning", and "self-control/check". The reliability and validity tests showed that the scale is appropriate for identifying high school students' metacognitive strategies. In the study undertaken by Namlu (2004) to develop a scale, the aim was to identify the subdimensions of metacognitive learning strategies and the study unearthed four subdimensions which are planning, organising, managing and evaluation. The analysis on this scale found that the "Metacognitive Learning Strategies Scale" is a valid and reliable scale to evaluate university students' metacognitive learning strategies.

Another study that was undertaken on learning strategies in Turkey is the adaptation of the "Inventory of Metacognitive Components" scale by Aktamış and Uça (2010) into Turkish. This scale was developed by Mok, Fan and Pand (2007) and it was based on Pintrich and De Groot (1990) and O'Neil and Abedi's (1996) studies. The original scale consisted of 6 factors and it had a total of 35 items. As a result of the adaptation study, it was found that the scale consisted of 6 factors that had 26 items in total. It was stated that the scale can be used starting from primary school second grades.

It is obvious that the researchers in all of these studies have dealt with different aspects of learning strategies, and based their research on different teaching grades. In the literature review, it is observed that there is a lack of a scale which can be used to identify undergraduate students' learning strategies. With the aim of filling in this gap, in this study the researchers have decided to undertake the adaptation of a scale designed for undergraduate students. Considering this need, this study aims to undertake the adaptation of the scale (LIST- Learning Strategies Scale (Fragebogen zur Erfassung von kognitiven Lernstrategien im Studium)) developed by Boerner et al. (2005) for undergraduate students in Germany into Turkish, and the study also aims to investigate the equivalence, reliability and validity of the Turkish version of the LIST Learning Strategies Scale. As a result of the study conducted in this context, a Turkish scale would be considered as an instrument to be used in determining the learning strategies of university students. In the following sections the validity and reliability study of LIST 
Learning Strategies Scale will be explained in detail. The current study is significant in that it will help students identify their own learning styles/strategies and achieve more efficient learning by using these strategies. Moreover, this study will contribute to the literature by undertaking the adaptation study of a learning strategies scale that can be applied to all undergraduate students and their lessons, and it is thought that the Turkish form of the adapted scale can be used as an efficient data collection tool in the studies that are undertaken in this field. This finding also reveals the research problem of the study as well as its difference from other similar studies.

\section{METHOD}

\section{The Participants}

In determining the participants of the study, purposive stratified sampling method, one of the ways of random sampling, was used. In purposive sampling, researchers choose the samples which they think will provide the data they need according to their own evaluation (Fraenkel and Wallen, 2003: 105). The studies revealed that the data obtained from the research that used purposive sampling method yielded to as reliable results as those obtained from the random sampling research. 754 university students having a formal education at a state university in the Central Anatolian District of Turkey make up the participants of this study. 32\% (241) of the students pursue a degree in Pre-School Education, 29\% (219) in Foreign Language Education, 10\% (76) in Teaching of Turkish, 9\% (68) in Physical Education, 9\% (67) in Social Sciences Education, 6\% (45) in Maths Education and 5\% (36) pursue a degree in Music Education. 58\% (437) of the participants are females while $42 \%$ are males. As the studies on scale development are based on the correlation among items, the size of the participants is regarded as a significant factor that influences the results in these kinds of studies. While making a decision on the sample size, the literature was checked and it was found that at least 200 valid participants were needed (Gallant, 2007). While 300 observations are seen as a good representation by some researchers (Field,2013), the common view suggests that it is the number of items that is the decisive factor and that the ideal number of participants should be 5 to 10 times bigger than the number of the items (MacCallum, Widaman, Zhang \& Hong, 1999). In accordance with these criteria, the study group, accessed through an easily available sampling method, could be argued to be sufficient regarding the number of the items in the scale.

\section{LIST- Learning Strategies Scale in Higher Education}

Horner et al. (2005) developed the LIST scale [LIST- Fragebogen zur Erfassung von kognitiven Lernstrategien im Studium) by developing a model, in which 13 factors in the main dimensions of learning strategies exist, to identify the factors that affect university students' academic success the most. The scale is a self-report tool which identifies students' learning strategies through their own responses. In the scale, general statistical analyses and psychometric analyses (internal validity, factor analysis, correlation and so on) were used.

LIST is a scale based on Wild and Schiefele's (1994) study and it aims to assess affective, cognitive and metacognitive strategies. Boerner at al. (2005) defined cognitive 
strategies as the strategies students use to perform their academic duties or to improve their social skills in the learning process. They defined affective strategies as the strategies which help remove the motivational and affective obstacles and finally, they defined metacognitive strategies as the strategies which consist of the skills of monitoring learning that is used by learners actively during learning. The theoretical background (model) of The Learning Strategies Scale (LIST), based on learning strategies dimensions, was given in Table 1 below (Boerner et al., 2005).

Table 1

The Theoretical Model of the Learning Strategies Dimension of LIST

\begin{tabular}{|c|c|c|}
\hline Main Components & Factors & Behaviour Examples \\
\hline Cognitive Strategies & $\begin{array}{l}\text { - Rehearsal } \\
\text { - Critical Thinking } \\
\text { - Association } \\
\text { - Organisation }\end{array}$ & $\begin{array}{l}\text { mental repetition, memorisation, remembering knowledge in situations } \\
\text { where knowledge is asked to be learned. } \\
\text { decision making, making critical evaluations, problem solving. } \\
\text { making comparison and contrasts with prior and new information. } \\
\text { reorganising knowledge according to yourself. } \\
\text { schematising knowledge, tabulation. } \\
\text { breaking information into meaningful components. } \\
\text { summarising, note taking }\end{array}$ \\
\hline Affective Strategies & $\begin{array}{l}\text { - Effort Management } \\
\text { - Time Management } \\
\text { - Studying Environment } \\
\text { - Concentration } \\
\text { - Peer Cooperation } \\
\text { - Using references } \\
\end{array}$ & $\begin{array}{l}\text { persistence in doing difficult tasks and subjects. } \\
\text { maintaining effort in given tasks. } \\
\text { using time efficiently and actively. } \\
\text { organising the learning environment. } \\
\text { focusing attention on the learning unit, concentration. } \\
\text { learning in cooperation. } \\
\text { making use of sources such as books and journals. }\end{array}$ \\
\hline $\begin{array}{l}\text { Metacognitive } \\
\text { Strategies }\end{array}$ & $\begin{array}{l}\text { Planning } \\
\text { - Arrangement } \\
\text { - Control of Learning }\end{array}$ & $\begin{array}{l}\text { setting goals, analysing tasks. } \\
\text { ensuring controlling and arranging behaviours in improving performance. } \\
\text { questioning whether learning has taken place or not. } \\
\text { self-evaluation. }\end{array}$ \\
\hline
\end{tabular}

The scale has rehearsal, critical thinking, association and organisation factors in cognitive dimension; effort management, time management, studying environment, concentration, peer cooperation and reference use factors in affective dimension and planning, arrangement and controlling learning factors in metacognitive dimension.

The scale consists of 13 factors and 85 items in total. These are: organisation strategies (9 items), association strategies (8 items), critical thinking strategies (8 items), rehearsal strategies (8 items), effort management strategies ( 8 items), concentration strategies (6 items), time management strategies (4 items), studying environment strategies (6 items), peer cooperation strategies (4 items), literature use strategies (4 items), planning strategies (6 items), arrangement strategies (8 items) and control of learning strategies (6 items). The scale lasts around twenty to thirty minutes. Participants use ratings in a Likert-type scale whose options range from 1 (definitely wrong) to 6 (definitely true).

\section{Procedures}

\section{The Translation of the LIST Learning Strategies Scale into Turkish}

While the scale was being translated into Turkish, the aim was to choose the most appropriate sentence structure, translate the idioms without losing their meaning and use the Turkish versions as much as possible for the cultural words that are foreign to Turkish culture. The adaptation of the scale into Turkish language was conducted in the 
frame of the suggestions by Hambleton and Patsula (1999) with regard to intercultural test adaptation. Considering the target of the scale, the translation stage was undertaken meticulously via spending sufficient time. The scale was translated from German into Turkish by three professionals (they all were at an advanced level of both languages) independently. These translations were checked and a temporary Turkish form was created. Then, the Turkish form, cultural context, grammar, research methodology, and assessment and evaluation criteria were submitted to the three professionals for review. In accordance with the suggestions, some revisions were made and the final Turkish form was prepared. The form was translated back into German via back translation method by two linguists and a professional pedagogue who is proficient in German. The Turkish and German versions were compared by two faculty in the School of Foreign Languages. The professionals stated that these forms reflected the same views as the original one. For the linguistic equivalence study of the LIST Learning Strategies Scale, 30 participants (who had proficiency in both languages) having education in Foreign Language Teaching Department in Ahmet Keleşoğlu Faculty of Education at Necmettin Erbakan University were chosen considering the advice of the faculty members. The correlation between the points students received from the German and Turkish one was taken as the equivalence indicator. By analysing the results of the equivalence study, the correlations were defined. To identify the dimensions of the LIST Learning Strategies Scale, exploratory factor analyses were undertaken.

\section{Data Analysis}

The data belonging to the scale consisting of 85 items were input via a computer. In the scale which has 6-item (1-6) Likert-type items, "definitely wrong for me" is rated as 1 while "definitely" true for me is rated as 6 . Rotation process was undertaken for the 11 reverse-coded items in the scale. The lowest point that can be obtained from the scale is 85 while it is 510 for the highest.

Before doing the initial analysis for the scale, total points were calculated for each student's data, and missing and extreme values were checked. For missing values, the frequency table was analysed and for identifying multivariate extreme values mahalanobis distance was checked. 12 of the observations were excluded from the data set as they included missing/erroneous values. Mahalanobis distance was calculated as $\mathrm{X} 2(85)=131.041,(\mathrm{p}<.001)$ for the scale which had 85 items. 108 observations that were above this value were also removed from the data set. In order to identify the factor structure of the scale, we made use of exploratory factor analysis (Çokluk, Şekercioğlu \& Büyüköztürk, 2010) which was used to convert many related variables into a few meaningful new variables. As suggested by Netemeyer, Bearden and Sharma (2003), while deciding on the factor structure of the scale, eigenvalues, scree plots and results of parallel analysis obtained from exploratory factor analyses were considered.

In parallel analysis, a random series correlation matrix which was obtained through Monte Carlo simulation was used. This matrix included the same number of participants and variables as the original data. Random series correlation matrices were analysed through principal component analysis and the averages for the obtained eigenvalues were calculated. The eigenvalue averages based on random correlation matrix and the 
eigenvalues calculated from the original data were compared. As a criterion for deciding on the number of factors, the cut-off point in which the calculated eigenvalues were bigger than the calculated eigenvalues was selected. O'Connor (2000), Henson and Roberts (2006) argued that the values in parallel analysis are obtained via simulating the original data and accordingly it is the most reliable method to obtain factors. In this study the parallel analysis calculations were made via the syntax created by O'Connor (2000). The results of the scale obtained through parallel analysis were attained through 100 repeated simulations and they were presented together with the results of the exploratory factor analysis.

Although there is not a limit for the shared variance values obtained from exploratory factor analysis results, it was ensured that the value was above 10 (Çokluk, Şekercioğlu \& Büyüköztürk, 2010), its factor loads in factorising was ,32 and above (Comrey \& Lee, 1992) and the same item did not exist in more than one factor (cross-loading).

\section{FINDINGS}

\section{Findings regarding Linguistic Validity}

While adapting LIST, firstly, the linguistic and cultural equivalence analyses suggested by Hambleton and Patsula (1999) were undertaken. In order to ensure linguistic equivalence, the translation was applied to 30 students who studied at German Language Teaching department. They were proficient in both German and Turkish. The ratings from the whole scale and its subdimensions were calculated taking the original scale as the base. In the table below the significance of the students' average ratings for the dimensions in the translation and the original version were given.

Table 2

Original Scale and Translated Scale mean differences

\begin{tabular}{|c|c|c|c|c|c|c|c|}
\hline & \multicolumn{3}{|c|}{ Original Scale } & \multicolumn{2}{|c|}{ Translated Scale } & \multirow[b]{2}{*}{$t$} & \multirow[b]{2}{*}{$\mathrm{p}$} \\
\hline $\begin{array}{l}\text { Dimensions } \\
\text { simas }\end{array}$ & $\mathrm{n}$ & Mean & Ss. & Mean & Ss. & & \\
\hline Organisation & & 41,74 & 6,74 & 41,29 & 7,92 & ,237 & ,813 \\
\hline Effort Management & & 34,08 & 5,06 & 35,07 & 6,81 &,- 637 & ,527 \\
\hline Planning & & 21,55 & 4,73 & 21,60 & 3,39 &,- 051 & ,959 \\
\hline Learning Control & & 22,94 & 5,24 & 23,64 & 4,91 &,- 534 & ,596 \\
\hline Arrangement & & 34,14 & 5,25 & 34,38 & 6,85 &,- 153 & 879 \\
\hline Concentration & & 19,00 & 8,27 & 19,47 & 6,28 &,- 246 & ,807 \\
\hline Time Management & 30 & 16,35 & 4,94 & 16,13 & 4,97 & , 169 & ,867 \\
\hline Study Environment & & 27,93 & 6,10 & 28,97 & 6,08 &,- 657 & ,514 \\
\hline Peer Cooperation & & 17,10 & 4,38 & 18,23 & 3,78 & $-1,073$ & ,288 \\
\hline Literature Use & & 20,13 & 3,46 & 18,33 & 3,61 & 1,970 & 054 \\
\hline Organising & & 36,24 & 7,28 & 36,57 & 7,07 &,- 177 & ,860 \\
\hline Critical Thinking & & 33,01 & 7,58 & 34,23 & 7,13 &,- 642 &, 523 \\
\hline Rehearsal & & 35,27 & 9,01 & 36,07 & 6,97 &,- 385 & ,702 \\
\hline
\end{tabular}

When the table was studied, it was observed that students had similar averages regarding the dimensions in both applications. Except for the "Literature Use" dimension, the difference was found to be non-significant $(p, 05)$ for all the dimensions. The 
significance level of the difference between the original and the translated scale regarding Literature Use was also on the borderline $(\mathrm{p}=, 054)$. The item in the limit value was revised and then added to the final application. In addition, the coefficient calculated for the points obtained in the first and second applications of the scale was found to be, 94 . The values of $t$ and correlation coefficient indicated that there is linguistic equivalence between the translation and the original form.

\section{Findings regarding Construct Validity}

In the exploratory factor analysis on construct validity, initially sample adequacy was analysed. In order to test sample data appropriateness, Keiser-Meyer-Olkin (KMO) coefficient and Bartlett's test results were considered. In the study the KMO coefficient for the appropriateness of the sample was found to be 93 . This value indicated that the sample had a sufficient sample size for the study. When the results of the Bartlett's test were analysed, it was understood that the values belonging to the distribution ( $\mathrm{x} 2=$ $27208.80, \mathrm{sd}=2556, \mathrm{p}<0.001)$ had appropriate values for exploratory factor analysis.

It was observed that the shared variance values (communalities) in the results of the first analysis which was done without applying the rotation process were above, 40 . In the table below the eigenvalues and parallel analysis results of the 85 items which were obtained through exploratory factor analysis were compared.

Table 3

Exploratory factor analysis results

\begin{tabular}{llllll}
\hline \multirow{2}{*}{ No } & \multirow{2}{*}{ Exp. Variance } & Total Exp. Variance & Eigenvalue & \multicolumn{2}{c}{ Coincidental/Random Data } \\
\cline { 3 - 5 } & & & & Average & $95 \%$ \\
\hline 1 & 23,983 & 23,983 & 20,39 & 1,74 & 1,80 \\
\hline 2 & 5,628 & 29,611 & 4,78 & 1,69 & 1,73 \\
\hline 3 & 4,182 & 33,793 & 3,55 & 1,65 & 1,68 \\
\hline 4 & 2,993 & 36,786 & 2,54 & 1,62 & 1,65 \\
\hline 5 & 2,601 & 39,387 & 2,21 & 1,59 & 1,62 \\
\hline 6 & 2,583 & 41,969 & 2,20 & 1,56 & 1,59 \\
\hline 7 & 2,267 & 44,236 & 1,93 & 1,54 & 1,56 \\
\hline 8 & 2,233 & 46,469 & 1,90 & 1,51 & 1,53 \\
\hline 9 & 2,049 & 48,518 & 1,74 & 1,49 & 1,51 \\
\hline 10 & 1,911 & 50,429 & 1,62 & 1,47 & 1,49 \\
\hline 11 & 1,837 & 52,266 & 1,56 & 1,45 & 1,47 \\
\hline 12 & 1,775 & 54,040 & 1,51 & 1,43 & 1,44 \\
\hline 13 & 1,693 & 55,734 & 1,44 & 1,41 & 1,42 \\
\hline 14 & 1,465 & 57,199 & 1,25 & 1,39 & 1,41 \\
\hline 15 & 1,370 & 58,570 & 1,16 & 1,37 & 1,39 \\
\hline 16 & 1,299 & 59,869 & 1,10 & 1,35 & 1,37 \\
\hline 17 & 1,246 & 61,115 & 1,06 & 1,33 & 1,35 \\
\hline 18 & 1,173 & 62,288 & 1,00 & 1,32 & 1,33 \\
\hline 19 & 1,140 & 63,428 & 97 & 1,30 & 1,32 \\
\hline 20 & 1,119 & 64,548 & 95 & 1,28 & 1,30 \\
\hline
\end{tabular}

When the results of the principal component analysis were studied together with the results of the parallel analysis, it was observed that the scale had a 13-dimensioned 
structure. If merely the eigenvalues that were bigger than 1 had been considered according to exploratory factor analysis, the scale could have had 18-factored structure. However, the findings of the parallel analysis, which provides stronger results compared to exploratory factor analysis, indicated a 13 -factored structure. The scatter plot used for interpreting parallel analysis results showed the junction point of the original data eigenvalues and random data eigenvalues which indicated the number of factors (O'Connor, 2000). When the table which presented these values above was analysed, it was understood that the eigenvalues belonging to the initial 13 factors were bigger than the average and percentage of the eigenvalues of the coincidental data. For this reason, it was understood that the 13th junction factor indicated where the junction point was.

When the variance was analysed, the total variance explained by the 13 -factored structure was found as $55,73 \%$. It was observed that the first factor had the most contribution $(23,983 \%)$ and the second and third factors $(5,628 \%$ and $4,182 \%)$ were also the other highly-contributing factors. Erkuss (2016) argues that these values do not have a decisive role as they state the situation before the rotation process. The final values are argued to provide more meaningful results. As in the original form of the scale, by taking into consideration the 13 factors that were obtained as a result of the principal component analysis, the rotation process was applied. As in the original scale, rotation was undertaken depending on the 13 factors which were obtained in the principal components analysis. Taking the structure of the study as the base (Çokluk et al., 2010), Promax, which is a type of skewed rotation technique, was used. As suggested by Tabachnick and Fidell (2007), for defining the item loads the ,32 limit was taken as the base.

After the rotation process, as the 26, 27, 28 and 29th items belonging to the factor "learning control belief" were below the ,32 line, they were removed and 24 and 25th items were removed as well as they were found to be indecisive. As this factor was removed completely, the rotation process was re-applied as 12 factors. After this process, 1, 9, 14, 20, 21, 30, 33, 34, 36, 37, 70 and 78th items were excluded from the scale as they were below ,32 and as they had cross-loading values. The final scale consists of 12 factors and 67 items. The final items left in the scale and the factor load values of the items were presented in the table appendix.

After the rotation process, it was observed that the 12-factored new structure accounted for the $59,89 \%$ of the total variation. When the factor loads of the items in the scale were examined, it was observed that the values of the factors were between , 34 and ,92. It was found that the loads of the final factors and items obtained from the scale were similar to the findings of Boerner et al. (2005).

\section{Findings on Reliability}

The average, standard deviation and correlation coefficient values were studied through the points obtained from the LIST scale. In addition, to specify reliability, Cronbach alpha values were calculated for both the whole scale and also its dimensions. The results of Cronbach alpha test, averages, standard deviation and interdimensional correlation values were presented in the table below. 
Table 4

Reliability statistics of LIST scale

\begin{tabular}{|c|c|c|c|c|c|c|c|c|c|c|c|c|}
\hline & 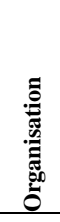 & 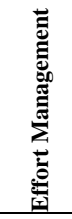 & 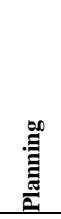 & 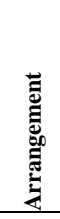 & 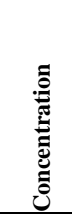 & 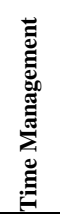 & 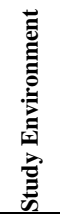 & 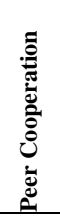 & 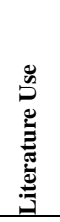 & 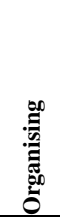 & 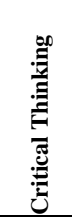 & $\begin{array}{l}\text { Cr. } \\
\text { Alpha }\end{array}$ \\
\hline Organisation & 1 & & & & & & & & & & & 0,81 \\
\hline Effort Management & $\begin{array}{l}, 542 \\
* *\end{array}$ & 1 & & & & & & & & & & $\mathbf{0 , 8 0}$ \\
\hline Planning & $\begin{array}{l}310 \\
* * *\end{array}$ & $\begin{array}{l}, 359^{*} \\
*\end{array}$ & 1 & & & & & & & & & 0,71 \\
\hline Arrangement & $\begin{array}{l}, 352 \\
* * *\end{array}$ & $\begin{array}{l}, 384 * \\
*\end{array}$ & $\begin{array}{l}, 284 \\
* *\end{array}$ & 1 & & & & & & & & 0,74 \\
\hline Concentration & $\begin{array}{l}, 217 \\
* * *\end{array}$ & $\begin{array}{l}, 310^{*} \\
*\end{array}$ & $\begin{array}{l}, 341 \\
* *\end{array}$ & $\begin{array}{l}, 154 \\
* * *\end{array}$ & 1 & & & & & & & 0,91 \\
\hline Time Management & $\begin{array}{l}, 331 \\
* * *\end{array}$ & $\begin{array}{l}, 399 * \\
*\end{array}$ & $\begin{array}{l}, 305 \\
* *\end{array}$ & $\begin{array}{l}, 242 \\
* * *\end{array}$ & $\begin{array}{l}, 190 * \\
*\end{array}$ & 1 & & & & & & 0,82 \\
\hline Study Environment & $\begin{array}{l}, 449 \\
* * *\end{array}$ & $\begin{array}{l}, 442 * \\
*\end{array}$ & $\begin{array}{l}, 296 \\
* *\end{array}$ & $\begin{array}{l}, 322 \\
* * *\end{array}$ & $\begin{array}{l}, 125^{*} \\
*\end{array}$ & $\begin{array}{l}, 337 \\
* *\end{array}$ & 1 & & & & & $\mathbf{0 , 8 0}$ \\
\hline Peer Cooperation & $\begin{array}{l}, 309 \\
* * *\end{array}$ & $\begin{array}{l}, 265^{*} \\
*\end{array}$ & $\begin{array}{l}, 146 \\
* *\end{array}$ & $\begin{array}{l}, 226 \\
* * *\end{array}$ &,- 001 & $\begin{array}{l}, 178 \\
* *\end{array}$ & $\begin{array}{l}, 350 \\
* *\end{array}$ & 1 & & & & 0,79 \\
\hline Literature Use & $\begin{array}{l}\text {, 479 } \\
* * *\end{array}$ & $\begin{array}{l}, 463^{*} \\
*\end{array}$ & $\begin{array}{l}, 281 \\
* *\end{array}$ & $\begin{array}{l}, 398 \\
* * *\end{array}$ & $\begin{array}{l}, 255^{*} \\
*\end{array}$ & $\begin{array}{l}, 281 \\
* *\end{array}$ & $\begin{array}{l}, 462 \\
* *\end{array}$ & $\begin{array}{l}, 321 \\
* * *\end{array}$ & 1 & & & $\mathbf{0 , 8 3}$ \\
\hline Organising & $\begin{array}{l}, 531 \\
* * *\end{array}$ & $\begin{array}{l}, 443^{*} \\
*\end{array}$ & $\begin{array}{l}, 355 \\
* * *\end{array}$ & $\begin{array}{l}, 418 \\
* * *\end{array}$ & $\begin{array}{l}, 208 * \\
*\end{array}$ & $\begin{array}{l}, 329 \\
* *\end{array}$ & $\begin{array}{l}, 461 \\
* *\end{array}$ & $\begin{array}{l}, 360 \\
* * *\end{array}$ & $\begin{array}{l}, 584 \\
* * *\end{array}$ & 1 & & $\mathbf{0 , 8 9}$ \\
\hline Critical Thinking & $\begin{array}{l}, 421 \\
* * *\end{array}$ & $\begin{array}{l}, 314^{*} \\
*\end{array}$ & $\begin{array}{l}, 287 \\
* * *\end{array}$ & $\begin{array}{l}, 315 \\
* * *\end{array}$ & $\begin{array}{l}, 110^{*} \\
*\end{array}$ & $\begin{array}{l}, 279 \\
* * *\end{array}$ & $\begin{array}{l}, 330 \\
* * *\end{array}$ & $\begin{array}{l}, 239 \\
* * *\end{array}$ & $\begin{array}{l}, 457 \\
* * *\end{array}$ & $\begin{array}{l}, 628 \\
* * *\end{array}$ & 1 & $\mathbf{0 , 8 7}$ \\
\hline Rehearsal & $\begin{array}{l}\text {, 488 } \\
* * *\end{array}$ & $\begin{array}{l}, 467 * \\
*\end{array}$ & $\begin{array}{l}, 220 \\
* *\end{array}$ & $\begin{array}{l}, 344 \\
* * *\end{array}$ & $\begin{array}{l}, 130 * \\
*\end{array}$ & $\begin{array}{l}, 359 \\
* *\end{array}$ & $\begin{array}{l}, 438 \\
* *\end{array}$ & $\begin{array}{l}\text {,346 } \\
* * *\end{array}$ & $\begin{array}{l}, 428 \\
* * *\end{array}$ & $\begin{array}{l}, 452 \\
* *\end{array}$ & $\begin{array}{l}, 335^{*} \\
*\end{array}$ & 0,86 \\
\hline
\end{tabular}

To identify the reliability of the study, the corrected item total correlation values were analysed and these values were observed to vary between 0.67 and 0.36 . In addition to item total correlation, using low-high (27\%) group technique, the t-test results for each item were analysed in order to understand how much the items in the scale can distinguish between individuals. It was observed that each item had meaningful results in distinguishing between the low and high groups, and t values varied between 19.44 and 5.85 .

When the Cronbach Alpha values in the original scale were analysed, it was observed that these values varied between .74 and .92. As for the Cronbach Alpha values that were obtained regarding the 12 -factored structure after the adaptation study, it can be argued that they were very similar to the ones obtained from the original scale. When the reliability and validity results of the study were analysed together, it was understood that the form of the scale that was translated into Turkish has validity and reliability values which are sufficient enough to be used in research studies. 


\section{DISCUSSION AND CONCLUSION}

When students have the skills to use learning strategies, learning different subjects will be realised in a shorter time, and less effort and time will be needed (Senemoğlu, 2010). Consequently, it is essential for students to learn how to utilise learning strategies and they should become aware of the potential benefits of using these strategies. As a result of the literature review undertaken to find out the scales used in identifying learning strategies, it was seen that there were not enough number of scales developed for students in higher education. Accordingly, in this study the aim was to adapt the LISTLearning Strategies Scale, which was developed by Boerner et al. (2005) for students in higher education, into Turkish.

In the process of translating the scale into Turkish, professionals proficient in both German and Turkish were consulted. After the translation process, the linguistic equivalence study was undertaken for the Learning Strategies Scale and the correlation coefficient between the Turkish and German forms were observed to be 94 . This result showed that the relationship between the Turkish and German forms were valid and that the Turkish translations of the items in the scale complied with the original German items at a good level.

Similar to the other scale adaptation studies (e.g. Dağhan \& Akkkoyunlu, 2011; Büyüköztürk et al., 2004) in Turkey, some of the items were excluded from the scale considering the cultural differences. The original scale consisted of 13 dimensions that had 85 items in total. In the factor analysis, all the items in the original scale were included. However, the 26, 27, 28 and 29th items belonging to the "belief in controlling learning" factor were discarded from the scale as their values were below ,32. The 24 and 25 th items were also discarded as they were statistically indecisive. As this factor was discarded totally, the rotation process was applied again on 12 factors. After the rotation process, the items that had load values and cross-loading values below the ,32 cut-off point were also discarded. Considering the Turkish literature related with the learning control dimension, some inconsistent findings were found in the studies related with learning strategies of the students at different grades (Çakmak et al., 2008; Ocak and Yamaç, 2013) and of university students (Güvenç, 2011; Ömür and Nartgün, 2013). Therefore, the exclusion of learning control dimension from the scale seems reasonable.

The final scale consists of 12 factors and 67 items. The scale explains 59,89\% of the total variance. The differences in the structure of the scale may be stemming from the social, economic, cultural and geographical differences between the two countries. This view may provide a research gap to be studied.

As a part of the reliability study of the LIST- Learning Strategies Scale, Cronbach alpha values were calculated for the whole scale and its dimensions. The Cronbach alpha value was found to be ,94 for the whole scale and it was found to be between ,71 and ,91 for the different dimensions. It was observed that Boerner et al.'s (2005) study, in which a scale was developed, also had similar results $(, 74$ to ,92). Regarding different dimensions, the results of this study are consistent with the studies (Blickle, 1996; Schreiber \& Leutner 1996) that were based on the theoretical structure defined by Wild 
and Schiefele (1994). One of these studies is the scale developed by Boerner et al. (2005) which also mostly adopted Wild and Schiefele's (1994) theoretical structure. These results demonstrated that the calculations and statistics done in this study on the relevant dimensions are reliable. The t test results undertaken for the item averages of the upper $27 \%$ and lower $27 \%$ groups showed that the differences were significant for all the items and sub-scale total points. This finding demonstrated that all the items in the scale are distinguishing items. In this study, confirmatory factor analysis for the scale was not carried out. It could be regarded as a limitation of the study that it was conducted by means of only the exploratory factor analysis.

Utilising the current form of the scale, empirical designs that study the effects of different methods and applications on learning strategies can specify how to study and evaluate students according to their individual characteristics. Also, the scale can be used to define the state of the students regarding the strategies they use in different education settings. Moreover, the cognitive and affective characteristics in the scale can be compared to different cognitive and affective characteristics via various correlation analyses or the consistency of this study can be checked against different learning strategies scales. The LIST Learning Strategies Scale, in the light of the suggestions made in this study, is expected to draw the attention of researchers and this study is expected to contribute to the future studies that deal with the concept of learning strategies. Through the results of this study, it is acknowledged that there is internal consistency between the 12-dimensioned structure of the LIST scale, which was adapted to Turkish, and the factors in the scale. The results also show that the scale serves its purpose, which is to define the learning strategies of the students in higher education. Therefore, it was found that the scale developed in the light of the obtained findings is a valid and reliable instrument that could be used in the studies conducted to determine the learning strategies of university students. Still, it could be said that some other studies conducted on different study groups might provide more comprehensive information about the validity and reliability of the scale. It could also be argued that the results obtained from those studies might lead the way for new studies into the learning strategies of university students and the relationship between those strategies and different student characteristics.

\section{REFERENCES}

Akin, A., Abaci, R., \& Çetin, B. (2007). The Validity and Reliability of the Turkish Version of the Metacognitive Awareness Inventory. Kuram ve Uygulamada Egitim Bilimleri, 7(2), 671.

Aktamış, H., \& Uça, S. (2010). Motivasyonel, Bilişsel ve Bilişüstü Yeterlilikler Ölçeği'nin Türkçeye Uyarlanması. Illköğretim Online, 9(3) 980-989.

Altun, S., \& Erden, M. (2006). Öğrenmede Motive Edici Stratejiler Ölçeğinin Geçerlik ve Güvenirlik Çalışması. Yeditepe Üniversitesi. Edu7, 2(1), 1-16.

Apps, J. W., \& Apps, J. W. (1990). Study skills for today's college student. McGrawHill. 
Baş, G. (2012). The Effect of Teaching Learning Strategies in an English Lesson on Students' Achievement, Attitudes, and Metacognitive Awareness. Journal of Theoretical Educational Science, 5(1), 49-71.

Belet, Ş., \& Yaşar, Ş. (2007). Öğrenme Stratejilerinin Okuduğunu Anlama ve Yazma Becerileri ile Türkçe Dersine İlişkin Tutumlara Etkisi. Eğitimde Kuram ve Uygulama, 3(1), 69-86.

Blickle, G. (1996). Personality Traits, Learning Strategies, and Performance. European Journal of Personality, 10, 337-352.

Boerner, S., Seeber, G., Keller, H., \& Beinborn, P. (2005). Lernstrategien und Lernerfolg im Studium. Zeitschrift für Entwicklungspsychologie und Pädagogische Psychologie, 37(1), 17-26.

Büyüköztürk, Ş., Akgün, Ö. E., Kahveci, Ö., \& Demirel, F. (2004). Güdülenme ve Öğrenme Stratejileri Ölçeğinin Türkçe Formunun Geçerlik ve Güvenirlik Çalışması. Kuram ve Uygulamada Ĕgitim Bilimleri, 4(2), 207-239.

Çakmak, E. K., Akgün, Ö. E., Karadeniz, Ş., Büyüköztürk, Ş., \& Demirel, F. (2008). Determining Learning Stratagies and Motivation Level of Students in Primary Schools' Second Level and High Schools According to Course and Class Level. Journal of Human Sciences, 5(1).

Çokluk, Ö., Şekercioğlu, G. ve Büyüköztürk, Ş. (2010). Sosyal bilimler için çok değişkenli istatistik: SPSS ve LISREL uygulamalart. Ankara: Pegem Akademi.

Comrey, A. L., \& Lee, H. B. (1992). A first course in factor analysis. Hillsdale, NJ: Erlbaum.

Dikbaş, Y., \& Hasirci, Ö. K. (2008). Öğrenme Stratejileri Öğretiminin ve Ders İşlenişinde Kullaniminin Öğrencilerin Akademik Başarilarina ve Tutumlarina Etkisi. Ahi Evran Üniversitesi Kırşehir Ĕ̆itim Fakültesi Dergisi, 9(2).

Diseth, A. (2011). Self-Efficacy, Goal Orientations and Learning Strategies as Mediators Between Preceding and Subsequent Academic Achievement. Learning and Individual Differences, 21(2), 191-195.

Erkuş, A. (2016). Psikolojide ölçme ve ölçek geliştirme-I: Temel kavramlar ve işlemler. Pegem Akademi Ankara.

Field, A. (2013). Discovering statistics using IBM SPSS statistics. Sage.

Gagne, R. M. ve Driscoll, M.P. (1988). Essentials of learning for instruction. Englewood Cliffs, N. J. : Prentice Hall.

Güvenç, H. (2011). Yansıtma Materyalleriyle Desteklenen İşbirlikli Öğrenmenin Türkçe Öğretmeni Adaylarının Özdüzenlemeli Öğrenmelerine Etkileri. Ĕgitim ve Bilim, 36(159). 
Hambleton, R. K., \& Patsula, L. (1999). Increasing the Validity of Adapted Tests: Myths to be Avoided and Guidelines for Improving Test Adaptation Practices. Journal of Applied Testing Technology, 1(1), 1-13.

Haşlaman, T., \& Aşkar, P. (2007). Programlama Dersi ile İlgili Özdüzenleyici Öğrenme Stratejileri ve Başarı Arasındaki İlişkinin İncelenmesi. Hacettepe Üniversitesi Eğitim Fakültesi Dergisi, 32(32).

Henson, R. K., \& Roberts, J. K. (2006). Use of Exploratory Factor Analysis in Published Research: Common Errors and Some Comment on Improved Practice. Educational and Psychological Measurement, 66(3), 393-416.

Karakış, Ö., \& Çelenk, S. (2007). Farklı Fakültelerde Öğrenim Gören Öğrencilerin Genel Öğrenme Stratejilerini Kullanma Düzeyleri "AİBÜ Örneği". Abant İzzet Baysal Üniversitesi Eğitim Fakültesi Dergisi.

Loranger, A. L. (1994). The Study Strategies of Successful and Unsuccessful High School Students. Journal of Reading Behavior, 26(4), 347-360.

Lynch, D. J. (2006). Motivational Factors, Learning Strategies and Resource Management as Predictors of Course Grades. College Student Journal, 40(2).

MacCallum, R. C., Widaman, K. F., Zhang, S., \& Hong, S. (1999). Sample Size in Factor Analysis. Psychological Methods, 4(1), 84.

Mok, Y. F., Fan, R. M. T., \& Pang, N. S. K. (2007). Developmental Patterns of School Students' Motivational and Cognitive Metacognitive Competencies. Educational Studies, 33(1), 81-98.

Muealas, A.\& Navarro, E. (2015). Learning Strategies and Academic Achievement. Procedia-Social and Behavioral Sciences. 217-221.

Namlu, A. G. (2004). Bilişötesi Öğrenme Stratejileri Ölçme Aracının Geliştirilmesi: Geçerlilik ve Güvenirlik Çalışması. Anadolu Üniversitesi Sosyal Bilimler Dergisi, 2, 123-136.

Netemeyer, R. G., Bearden, W. O. ve Sharma, S. (2003). Scaling procedures: Issues and applications. Sage Publications.

Ocak, G., \& Yamaç, A. (2013). İlköğretim Beşinci Sınıf Öğrencilerinin Öz-Düzenleyici Öğrenme Stratejileri, Motivasyonel İnançları, Matematiğe Yönelik Tutum ve Başarıları Arasındaki İlişkilerin İncelenmesi. Kuram ve Uygulamada Eğitim Bilimleri, 13(1), 369387.

O'connor, B. P. (2000). SPSS and SAS Programs for Determining the Number of Components Using Parallel Analysis and Velicer's MAP Test. Behavior Research Methods, Instruments, \& Computers, 32(3), 396-402.

O’Neil, H. F. \& Abedi, J. (1996). Reliability and Validity of a State Metacognitive Inventory: Potential for Alternative Assessment. The Journal of Educational Research, 89(4), 234-245. 
Ömür, Y. E., \& Nartgün, Ş. S. (2013). Öğretmen Adaylarının Öğretmenlik Mesleğine İlişkin Tutumları ile Güdülenme Düzeyleri Arasındaki İlişki. Eğitimde Politika Analizi Dergisi, 2(2), 41-55.

Özer, B. (1998). Öğrenmeyi öğretme, Eğitim Bilimlerinde Yenilikler. Ayhan Hakan (Editör). Eskişehir: Anadolu Üniversitesi Açıöğretim Fakültesi. 559: 147-162.

Öztürk, B. (1995). Genel öğrenme stratejilerinin ögrenciler tarafindan kullanılma durumları. Yayınlanmamış Doktora Tezi, Hacettepe Üniversitesi Sosyal Bilimler Enstitüsü, Ankara.

Pallant, J. (2007). SPSS survival manual. New York: McGraw-Hill.

Pintrich, P. R. \& De Groot, E. V. (1990). Motivational and Self-Regulated Learning Components of Classroom Academic Performance. Journal of Educational Psychology, 82 (1), 33-40.

Pintrich, P. R., Smith, D., Garcia, T. ve McKeachie, W.J. (1991). A manual for the use of the motivated strategies for learning questionaire. Michigan Universty Press.

Saban, A. İ., \& Tümkaya, S. (2008). Öğretmen Adaylarının Öğrenme Stratejileri ile Sosyo Demografik Özellikler ve Akademik Başarıları Arasındaki İlişsinin İncelenmesi. Ege Eğitim Dergisi, 9(1).

Schraw, G. \& Dennison, R. S. (1994). Assessing metacognitive awareness. Contemporary Educational Psychology, 19, 460-475.

Schreiber, B. \& Leutner, D. (1996). Diagnose von lernstrategien bei berufstätigen. [Identification of learning strategies among professionals] Zeitschrift für Differentielle und Diagnostische Psychologie, 17, 236-250.

Senemoğlu, N. (2005). Gelişim, Öğrenme ve Öğretim. (12.baskı). Ankara: Gazi Kitabevi.

Şimşek, A. (2006). Bilişsel stratejilerin öğretimi. içerik türlerine dayalı öğretim (1.baskl). Ali Şimşek (Editör). Ankara: Nobel Yayın Dağıtımı, 181-204.

Subaşı, G. (2000). Etkili Öğrenme: Öğrenme Stratejileri, Milli Ĕgitim Dergisi, 146, 1-4.

Tabachnick, B. ve G. ve Fidell, L. S. (2007). Using multivariate statistics (5th ed.) Boston: Allyn and Bacon.

Tunçer, B. \& Güven, D. (2007). Öğrenme Stratejileri Kullanımının Öğrencilerin Akademik Başarıları, Hatırda Tutma Düzeyleri ve Derse İlişkin Tutumları Üzerindeki Etkisi. Yüzüncü Yll Üniversitesi Eğitim Fakültesi Dergisi, 4(2), 1-20.

Ülger, M. (2003). İlköğretim altıncı sınıf sosyal bilgiler dersi Osmanlı Devletiee nin kuruluşu ünitesinde öğrenme stratejilerini öğrenmenin öğrenci erişisine etkisi. Gazi Üniversitesi, Ankara. 
Üredi, I. ve Üredi,L. (2005). İlköğretim 8.Sınıf Öğrencilerinin Öz-Düzenleme İnançlarının Matematik Başarısını Yordama Gücü. Mersin Üniversitesi Ĕgitim Fakültesi Dergisi. 1(2), 250-260.

Weinstein, C. E., \& MacDonald, J. D. (1986). Why does a School Psychologist Need to Know about Learning Strategies? Journal of School Psychology, 24 (3), 257-265.

Weinstein, C.E. ve Mayer, R. (1986). The teaching of learning strategies handbook of research on teaching. NewYork: Macmillan Publishing.

Wild, K.-P. \& Schiefele, U. (1994). Lernstrategien im studium: ergebnisse zur faktorenstruktur und reliabilität eines neuen fragebogens. [Learner Strategies in Higher Education: Results of Factor Structure and the Reliability of a New Questionnaire] Zeitschrift für Differentielle und Diagnostische Psychologie, 15, 185-200.

Yıldız, N. (2003). Illköğretim 5. sınıf fen bilgisi dersinde öğrencilere kazandırılan ögrenme stratejilerinin öğrencilerin akademik başarllarl ve hatırda tutma düzeyleri üzerindeki etkisi (Yayımlanmamıs Yüksek Lisans Tezi). Anadolu Üniversitesi, Eskişehir.

Zimmerman, B. J. (1994). Dimensions of Academic Self-Regulation: A conceptual framework for education. In D.H. Schunk and B. J. Zimmerman (Eds.). Self-Regulation of Learning and Performance (pp. 3-24). New Jersey: Lawrence Erlbaum Associates Publishers.

Appendix A

Factor Loading Values

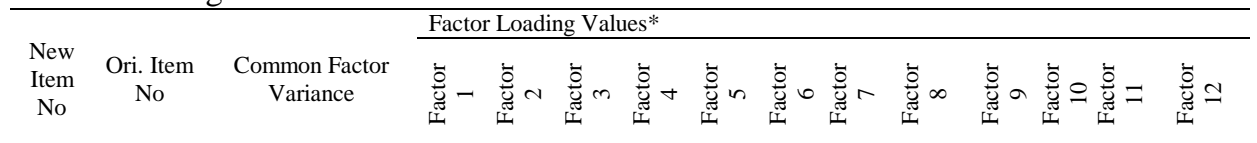

\begin{tabular}{|c|c|c|c|c|c|}
\hline i1 & i2 & ,602 & & 872 & \\
\hline i2 & i3 & ,638 & & ,832 & \\
\hline i3 & i4 & ,464 & ,326 & ,467 & \\
\hline i4 & i5 &, 583 & & ,799 & \\
\hline i5 & i6 &, 365 & & ,448 & \\
\hline i6 & i7 & ,536 & &, 790 & \\
\hline i7 & i8 & ,399 & &, 519 & \\
\hline i8 & $\mathrm{i} 10$ & ,435 & &, 442 & \\
\hline i9 & i11 & ,469 & &, 767 & \\
\hline i10 & i12 & ,669 & & 890 & \\
\hline i11 & i13 &, 532 & &, 734 & \\
\hline i12 & i15 & ,389 & &, 405 & \\
\hline i13 & i16 &, 450 & &, 604 & \\
\hline i14 & i17 & ,569 & & ,640 & \\
\hline i15 & i18 & ,556 & & &, 817 \\
\hline i16 & i19 & ,444 & & 210, 206 & ,340 \\
\hline i17 & $\mathrm{i} 22$ & ,640 & & &, 846 \\
\hline i18 & $\mathrm{i} 23$ & ,626 & & & ,838 \\
\hline i19 & $\mathrm{i} 31$ & ,616 & & & ,783 \\
\hline $\mathrm{i} 20$ & $\mathrm{i} 32$ & 685 & & & ,849 \\
\hline $\mathrm{i} 21$ & $\mathrm{i} 35$ & ,637 & & & ,735 \\
\hline
\end{tabular}




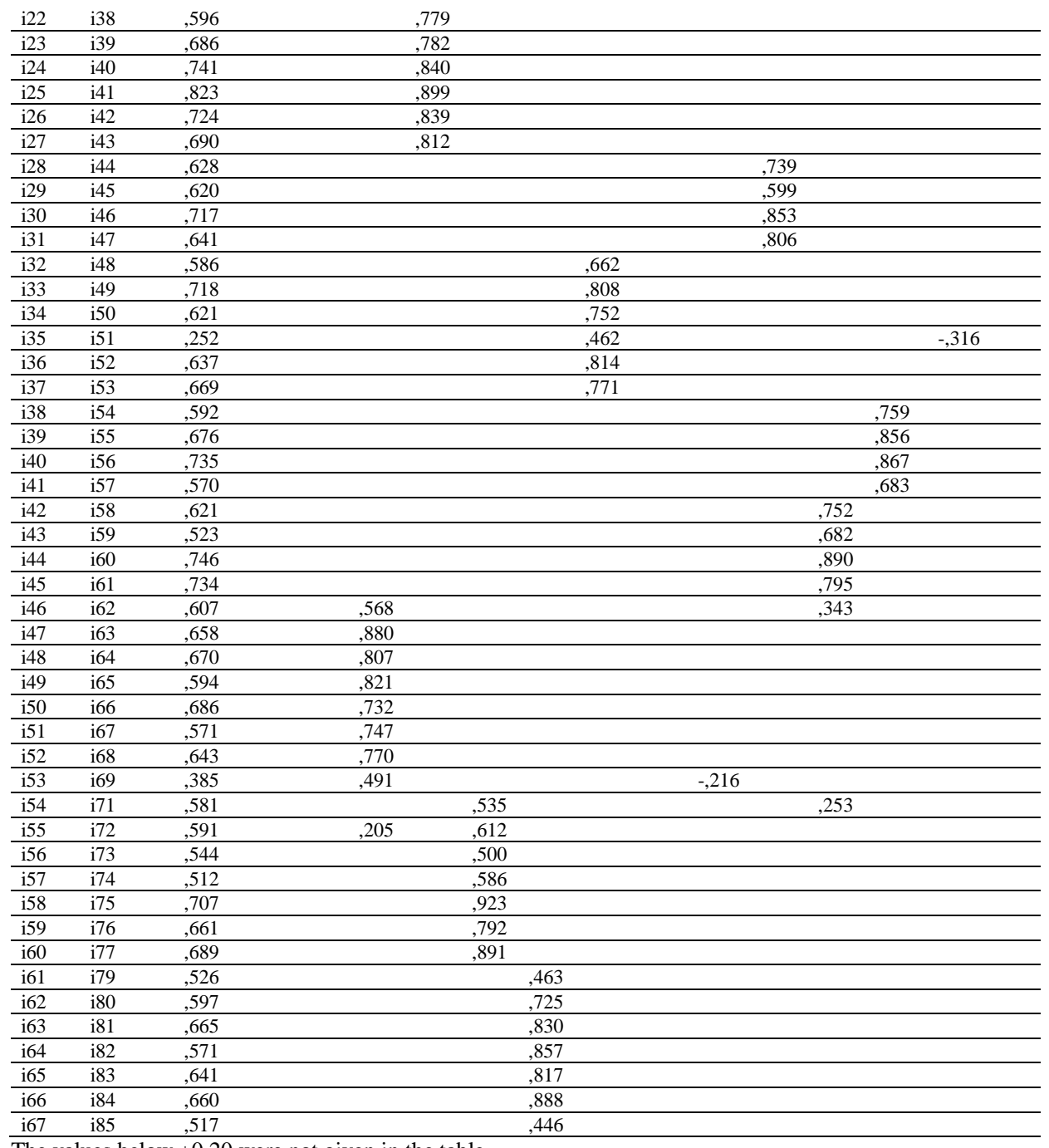

The values below $\pm 0,20$ were not given in the table. 